\title{
Procedure for Adopting Regional Managerial Decisions on the Basis of Applying DSS "DATA"
}

\begin{abstract}
Averchenkova E.E. Averchenkov A.V.
Bryansk State Technical University, Bryansk, Russia

"Corresponding author.Email: lena_ki@inbox.ru

ABSTRACT

The process of making managerial decisions at the regional level involving the resources of an automated system "DATA" (decision support system) is presented. The control object is a regional socio-economic system that operates in the context of implementing the National Projects of the Russian Federation. The external environment is shown to influence the formation of a regional managerial decision. The analysis of the external environment by the tools of the decision support system "DATA" allows you to determine many alternative managerial decisions and, based on the time factor, specify the optimal managerial decision as a selection criterion. The knowledge base of the software package contains a set of measures to achieve the goals of the Russian National Projects in the regional socio-economic system. The system of production rules used in the decision support system "DATA" makes it possible to form a set of corrective measures for managing the impact on the region, taking into account its specificity, as well as the versatile environmental impact. The regional manager is the person who makes the final decision on choosing specific managerial measures.
\end{abstract}

Keywords: managerial decisions, regional socio-economic system

\section{INTRODUCTION}

A managerial decision, assessing its effectiveness, especially the process of making a managerial decision at different levels of management in socio-economic systems has been considered in foreign and domestic scientific and practical literature for a long time. So, such Russian scientists as Vikhansky O.S. [1], Kuznetsova O.V. [2,3], Lexin V.N. [4,5], Naumov A.I. [6,7], Novikov D.A. [8,9], Pazyuk Yu.V., Porfiryev B.N. [10,11], Semechkin A.E., Shvetsov A.N. [12], as well as foreign scientists and practitioners M.Kh. Meskon, M. Albert, F. Hedouri, and others studied the process of making managerial decisions. A great contribution to realizing the features of managerial decision-making processes at the regional level was made by domestic practical scientists Kuzmenko I.P., Logua R.A. [13], Maslikhina V.Yu., Sesyunin S.Yu., Urasova A.A., Fattakhov R.V., Fedorchenko A.A., Chernikov A.P. and etc.

The authors determine that the managerial decisions made in relation to the regional socio-economic system (hereinafter referred to as RSES) are a combination of interconnected, focused and logically consistent managerial influences of the subject (civil servant) on the control object (RSES) [1]. Managerial decisions determine specific measures to achieve the goal (i.e., specific values of the indicators of the National Projects of the Russian Federation) within the framework of the overall objectives of controlling the object (i.e., fulfilling the goals of the
National Projects of the Russian Federation). Managerial decisions are simultaneously the result of taking into account the disturbing factor (external environment) and compensating for the error revealed by the feedback system $[5,10]$. When making managerial decisions at the regional level, managers, as a rule, rely on their own professional skills, past experience, intuition [4]. However, the information produced by the external environment of the RSES is characterized by increased complexity, heterogeneity and inconsistency. The risk of making the wrong or suboptimal decision increases for complex and unclearly worded tasks, relying only on intuition. It should be noted that modern systems of supporting decisions are widely used in public administration. However, Logua R.A. [13], Balyukov A.S., Ruzhnikov V.A. determine a significant reserve in applying the DSS in the area of staterun regional management, since regional DSSs are mainly focused on analytic and territorial information which is the tool for modeling the region development in the field of socio-economic indicators. The work defines how managers at various levels of regional authorities can use the DSS "DATA" in their activities in the format of a typical civil servant automated workstation. Automating decisionmaking support is the direction of optimizing the managerial activity and it differs favorably from decisions made using the traditional methods, based on the manager's intuition or on the concept of "common sense". 


\section{SUBJECT AREA OF THE RESEARCH}

The management system of the regional socio-economic system (MS RSES) was considered by the authors in a number of previous publications [14, 15]. Its visual representation is shown in Fig. 1.

The main elements of the management system of the RSES are the external environment, the control object (RSES), measuring devices No. 1,2,3, and the control device (DSS "DATA"). From a functional point of view, this model uses a combined control principle that takes into account the negative feedback loop and the compensation circuit for errors and disturbances of the external environment (using measuring devices). The driving action $g(t)$ is understood as the target settings of the National Projects of the Russian Federation received by the control device. The negative feedback system corrects by the error $\boldsymbol{\varepsilon}(\mathbf{t})$ the set of measures that determine the managerial effect. The external environment generates disturbing influences of various natures $f(\mathbf{t})$, diagnosed by measuring devices and compensated by the control devices. The users of the DSS "DATA" are government employees (lower and middle-ranking managers in regional authorities) and they use it in the process of making managerial decisions. The output coordinates $y(\mathbf{t})$ make it possible to evaluate the effectiveness of managerial decisions made thanks to the negative feedback mechanism.

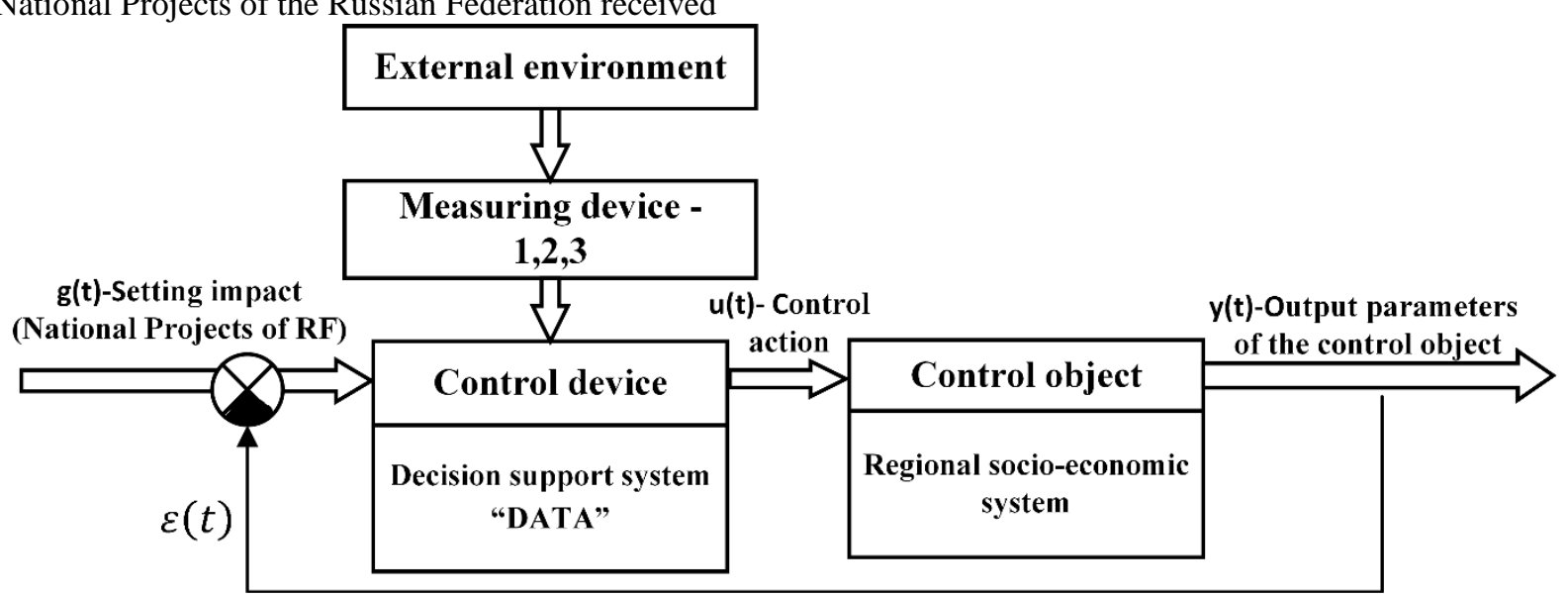

Figure 1 The management system of the regional socio-economic system

\section{RESEARCH METHODOLOGY}

It is possible to visualize the process of making managerial decisions at the regional level involving the DSS "DATA" resources using the scheme (Figure 2). In the above diagram, stages are highlighted in gray at which the regional manager can use the resources and capabilities of the DSS "DATA".
At the first stage of the management decision-making process, the DSS "DATA" provides a comprehensive information base that allows managers of the regional authorities to conduct a full-fledged analysis of the managerial situation, taking into account the target settings of the Russian National Projects. The analytical work of managers at various levels is associated with processing a large amount of primary and secondary information taken from open and closed sources.

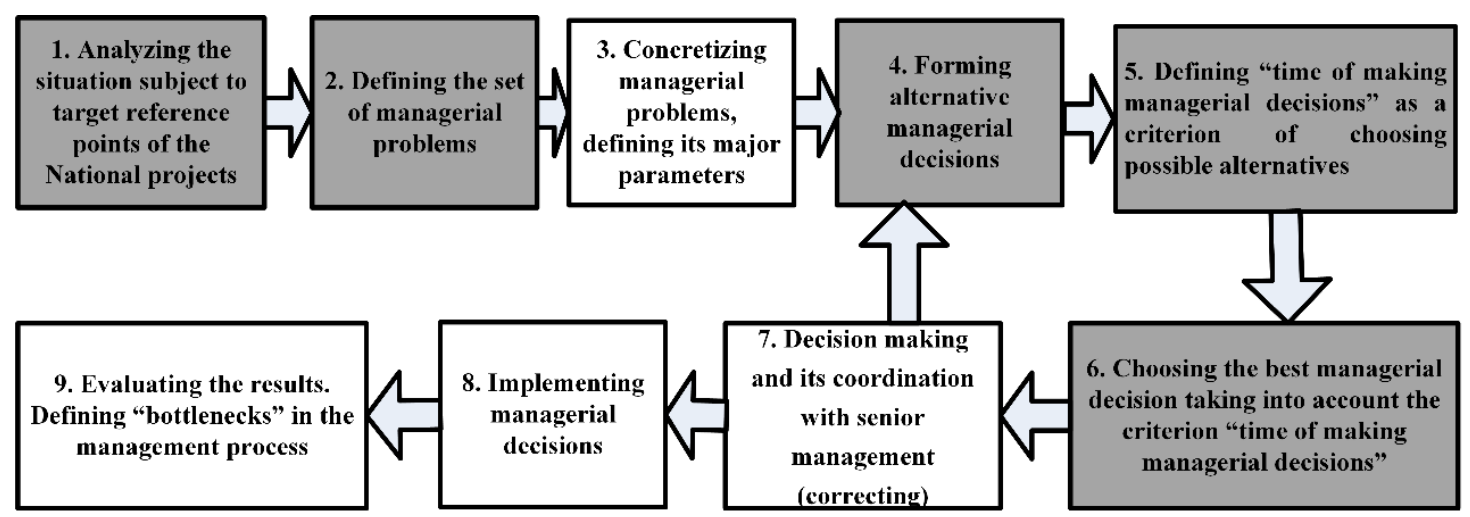

Figure 2 The process of making managerial decision at the regional level involving the DSS "DATA" resources 
Forming the information base for the subsequent analytics is provided by measuring devices No. 1, 2 and 3 (hereinafter MD No. 1, 2 and 3) [16]. So, for example, it is possible to assess the change in the influence of the external environment on the RSES (i.e., the dynamics of environmental disturbances) using expert assessment (MD №1) [17]. Carrying out analytics is provided by monitoring the external environment of the RSES, implemented by a software aggregator that combines data on the RSES taken from several sources to form a single user interface. (MD №2) [17]. Regularly conducted analytical and diagnostic actions to form the information base in the developed automated system provide the monitoring of the region state according to a number of targets for making subsequent effective managerial decisions (MD №3) [17]. Thus, the manager of the regional authorities can use the resources of the measuring system as an information-analytical system for tracking the regional situation. Further, the control device (DSS "DATA") selects and evaluates significant changes in specific indicators of the RSES based on an algorithm that determines the significance of the changes. Consequently, the concept of the significance of the event is formed. This concept is vital for making the conclusions which are the processing of the collected information. Thus, a machine-oriented advice-decision is formed, which independently diagnoses the RSES and creates the basis for forming managerial decisions.

At the second stage of the managerial decision-making process, the DSS "DATA" creates many managerial problems. So, each measuring device No. 1, 2 and 3 allows determining the subset of managerial problems, analyzed by the DSS "DATA".

At the third stage of the managerial decision-making process, the managerial problem is concretized by determining its parameters. This stage of the managerial process is carried out by the civil servant independently on the basis of attracting additional information, including the data taken from internal sources of regional authorities that are not represented in the DSS "DATA".

At the fourth stage of the managerial decision-making process, the regional manager may turn to the DSS "DATA" to form alternative managerial decisions. The knowledge base of the software package contains a set of measures to achieve the targets of the National Projects of the Russian Federation in the RSES. The system of production rules allows taking into account the influence of the external environment on the RSES. So, when forming logical rules for choosing alternative managerial decisions in the DSS "DATA", a unique production rule $R_{t}$ is formed for each management event $M_{t}$, depending on the influence of the RSES. Thus, for each component of the RSES, unique sets of production rules are determined in accordance with the request to the DSS "DATA". The sets of production rules $R_{a}$ for all components of the RSES form the production system in the DSS "DATA", which defines alternative managerial decisions. The manager makes the final decision on choosing specific management activities.

Further, in the process of making managerial decisions the leaders of the regional authorities can rely on the DSS
"DATA" in determining the time for making managerial decisions, which can be considered as a criterion for choosing decisions from possible alternatives in the classical formulation of the managerial process. Earlier in [18], it was shown that the criterion for assessing the performance of the MS RSES for appearing controlling and disturbing influences allowed the regional manager to

choose the term for error correction $\varepsilon(t)$. According to studies [18], the terms can be the following: $t=4$ months, $t$ $=1$ month or $\mathrm{t}=10$ days. The number of possible alternative managerial decisions and the time criteria for their selection will be different for the lower, middle-ranking and top management of the regional authorities, therefore, the automated program includes the ability to change the criteria for forming a list of recommended activities.

At the seventh stage of the managerial decision-making process, the decision is agreed upon with the senior management, if necessary, it is being finalized (at this stage, it is possible to return to the previous level when new alternative decisions proposed by the senior management are formed).

The eighth stage of the management process involves the implementation of the adopted and agreed decision. At the ninth stage, the results are evaluated for compliance with the target settings of the National Projects of the Russian Federation. An important point is defining "bottlenecks" in the management process, their subsequent adjustment.

Thus, the DSS "DATA" provides regional managers with the resources of a comprehensive and diverse information base for assessing the impact of the external environment on the RSES, which makes it possible to make an appropriate managerial decision.

\section{RESEARCH RESULTS}

Let's look at an example of how the management process is implemented involving the DSS "DATA" resources. Let a civil servant (for example, the head of the department for supporting and developing entrepreneurial activity in the Bryansk region) contact the DSS "DATA" to analyze the current regional situation in achieving the targets of the National project "Small and medium-sized enterprises and supporting individual entrepreneurial initiatives" for 2019. As a result of working with DSS "DATA", the civil servant will receive a set of managerial measures to correct the regional situation for this indicator of the supervised Russian National Project.

The measuring devices of the MS RSES, implemented in the DSS "DATA" software system, provide data for an appropriate analysis of the regional situation. The authors will show how measuring devices No. 1, 2, and 3 work on the example of one of the targets of the National Projects of the Russian Federation which is a component of the RSES "The number of people employed in the field of small and medium-sized enterprises, including individual entrepreneurs, mln people."

The analysis of the current regional situation using measuring device No.1 made it possible to identify factors 
of the strong influence of the external environment for the RSES component "The number of people employed in the field of small and medium-sized enterprises, including individual entrepreneurs" (Fig. 3).

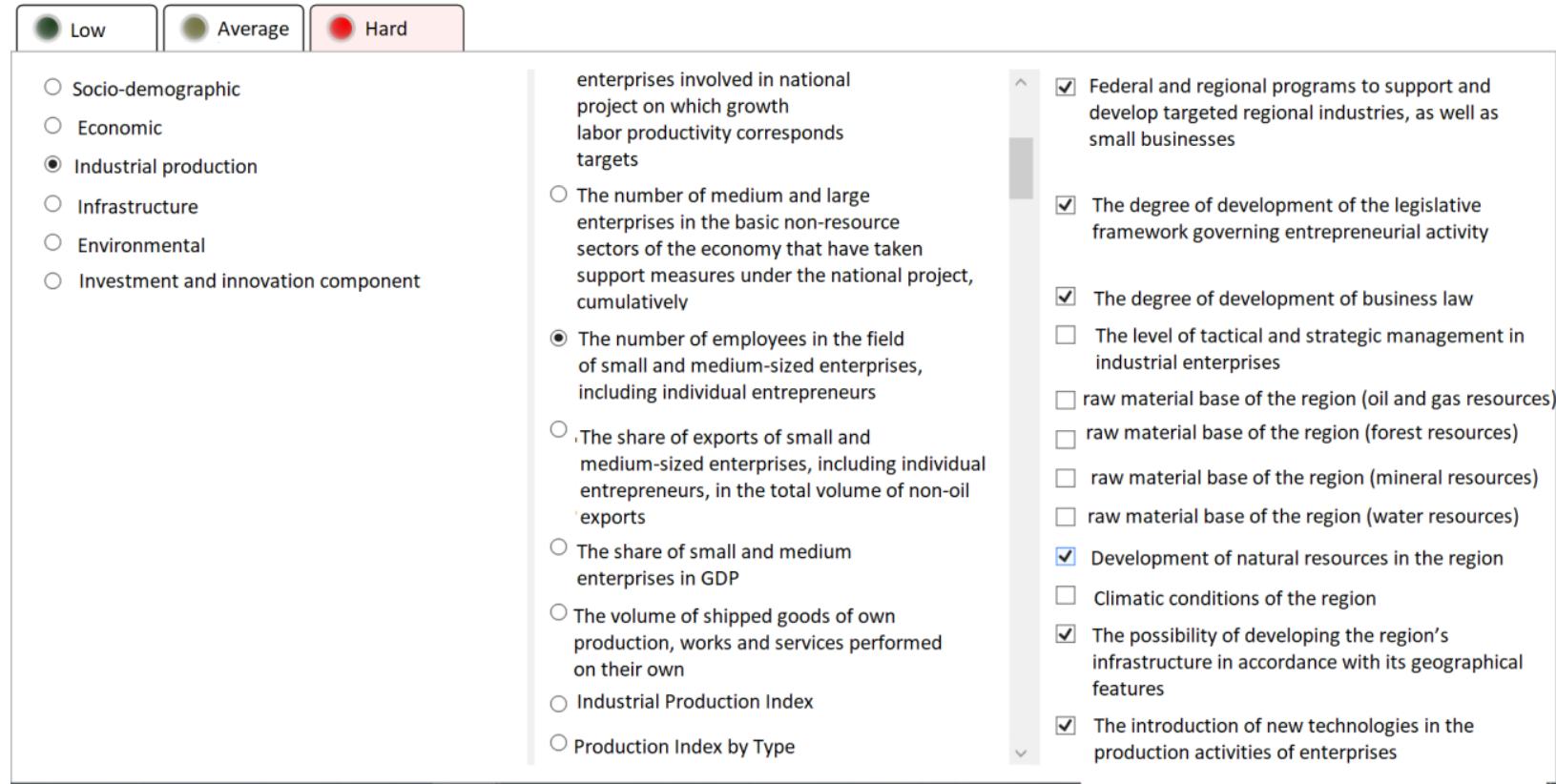

Figure 3 An example of working with measuring device No. 1 in the DSS "DATA" to determine the strong influence of the external environment on the RSES component "The number of employees in the field of small and medium-sized enterprises, including individual entrepreneurs"

Assessing the factors of the strong influence of the external environment made it possible to determine the most potential managerial problems of the regional scale. The

Table 1 Forming a subset of managerial problems using measuring device No. 1 for the RSES component "Number of employees in the field of small and medium-sized enterprises, including individual entrepreneurs"

\begin{tabular}{|l|l|}
\hline Environmental disturbances & Managerial problem \\
\hline $\begin{array}{l}\text { Administrative support for small business } \\
\text { initiatives at the regional level }\end{array}$ & $\begin{array}{l}\text { Amplifying the influence of the estimated disturbance is considered as a negative } \\
\text { signal, as this is due to weakening administrative support for entrepreneurial } \\
\text { initiatives }\end{array}$ \\
\hline$\cdots$ & $\ldots$ \\
\hline $\begin{array}{l}\text { Location of the region relative to the boundaries } \\
\text { with other states }\end{array}$ & $\begin{array}{l}\text { General political problems of relations with border areas level the competitive } \\
\text { advantages of the region }\end{array}$ \\
\hline $\begin{array}{l}\text { The proportion of the economically active } \\
\text { population in the population structure of the } \\
\text { region }\end{array}$ & $\begin{array}{l}\text { Reducing the proportion of economically active population in the structure of the } \\
\text { region population, which potentially leads to reducing entrepreneurial initiative }\end{array}$ \\
\hline
\end{tabular}

The work of measuring device №2 is based on aggregation and subsequent analysis of the data of the Open Data Portal of the Russian Federation (https://data.gov.ru). The authors consider that while analyzing the regional situation, MD №2 forms a request for the Open Data Portal of the Russian Federation in the direction of "small and medium-sized enterprises", and then aggregates the relevant information. As a result, the DSS "DATA" offers the civil servant a document "Statistical indicators of developing small and medium-sized enterprises (in the Bryansk Region)", which contains information on the number of people employed in small and medium-sized enterprises (Table 2). At the same time, the materiality threshold is calculated (described in [18]), a comparison with which allows determining for authors give a fragment of a subset of managerial problems formed by measuring device №1 in the form of table1. which periods it is exceeded. Thus, the managerial problem is formed by the toolkit of MD № 2 .

Thus, the calculated materiality threshold which equals 0.045 was exceeded twice, including in 2019 relative to 2018. Consequently, a managerial problem is being formed: in the last analyzed period the growth trend of the indicator is estimated as insufficient. An example of working with the DSS "DATA" for this indicator in MD № 2 is shown in Fig. 2. 
Table 2 Forming many managerial problems on the indicator "The average number of employees of small and medium-sized enterprises, including microenterprises (in the Bryansk region) in 2013-2019," by the toolkit of MD №2

\begin{tabular}{|c|c|c|c|c|c|c|}
\hline Period & $\begin{array}{c}\text { The average number } \\
\text { of employees } \\
\text { without external } \\
\text { part-time workers, } \\
\text { people }\end{array}$ & Period & $\begin{array}{l}\text { Relative chain } \\
\text { deviation of } \\
\text { indicators, } \%\end{array}$ & $\begin{array}{l}\text { Materiali } \\
\text { ty } \\
\text { threshol } \\
\text { d }\end{array}$ & $\begin{array}{l}\text { Exceeding } \\
\text { materiality threshold } \\
\text { for deviations of } \\
\text { indicators by years }\end{array}$ & Managerial problem \\
\hline 2013 & 48977 & - & - & \multirow{7}{*}{$-0,045$} & - & - \\
\hline 2014 & 48746 & $\begin{array}{l}2014 / \\
2013\end{array}$ & 0,99 & & 0 & - \\
\hline 2015 & 48003 & $\begin{array}{l}2015 / \\
2014\end{array}$ & 7,5 & & 0 & - \\
\hline 2016 & 46472 & $\begin{array}{l}2016 / \\
2015\end{array}$ & 0,12 & & 0 & - \\
\hline 2017 & 36387 & $\begin{array}{l}2017 / \\
2016 \\
\end{array}$ & $-32,17$ & & !!! & $\begin{array}{l}\text { Insufficient growth } \\
\text { trend }\end{array}$ \\
\hline 2018 & 47500 & $\begin{array}{l}2018 / \\
2017 \\
\end{array}$ & 28,55 & & 0 & - \\
\hline 2019 & 44861 & $\begin{array}{c}2019 / 2 \\
018 \\
\end{array}$ & $-5,26$ & & !!! & $\begin{array}{l}\text { Insufficient growth } \\
\text { trend }\end{array}$ \\
\hline
\end{tabular}

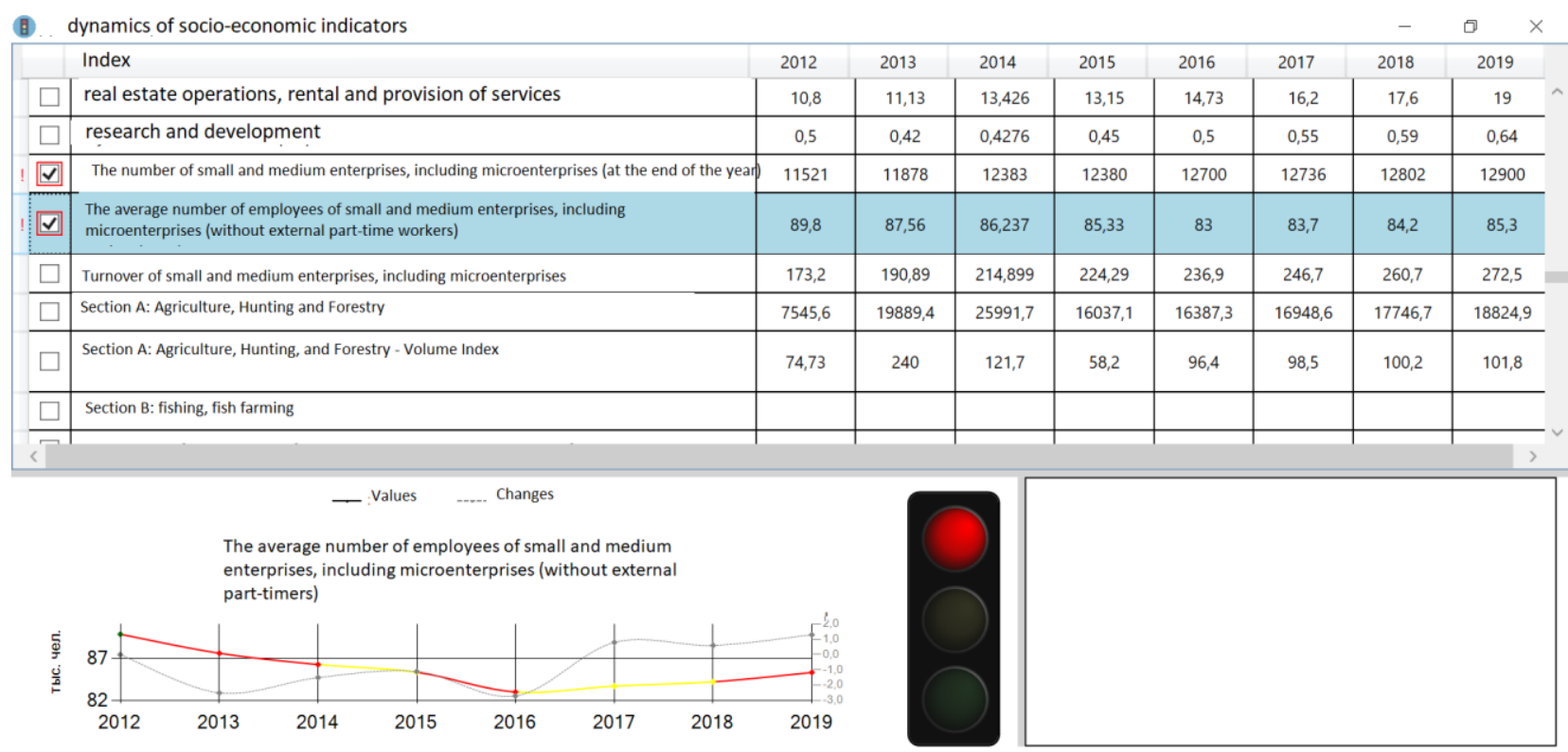

Figure 2 An example of working MD № 2 in the DSS "DATA" to identify a managerial problem in the indicator "Average number of employees of small and medium-sized enterprises, including microenterprises (in the Bryansk region) in 2013-2019"

Forming many managerial problems using measuring device № 3 can also help the civil servant in analyzing the current regional situation in the area of achieving the targets of the National project "Small and medium-sized enterprises and supporting individual entrepreneurial initiatives" for 2019. Measuring device №3 "Dynamics of indicators of the socio-economic development of the RSES" suggests the existence of related indicators for the component "Number of employees in the field of small and medium-sized enterprises, including individual entrepreneurs, million people". The format of the main

indicators presented for developing a forecast for the socioeconomic development of the Russian Federation (for the constituent entities of the Russian Federation) in form $2 \mathrm{P}$ includes such an indicator as "The number of small and medium-sized enterprises, including microenterprises (at the end of year)". The dynamics of this indicator can be considered as similar to the dynamics of the initial indicator 
(Table 3). Forming a managerial problem occurs with the use of the materiality threshold described in [18].

Table 3 Forming the set of managerial problems for the indicator "The number of small and medium-sized enterprises, including microenterprises (at the end of year)" by using measuring device №3

\begin{tabular}{|c|c|c|c|c|c|c|}
\hline Period & $\begin{array}{l}\text { The number of small and } \\
\text { medium-sized enterprises, } \\
\text { including microenterprises } \\
\text { (at the end of year }\end{array}$ & Period & $\begin{array}{l}\text { Relative chain } \\
\text { deviation of } \\
\text { indicators, } \%\end{array}$ & $\begin{array}{l}\text { Materiality } \\
\text { threshold }\end{array}$ & $\begin{array}{l}\text { Exceeding } \\
\text { materiality } \\
\text { threshold for } \\
\text { deviations of } \\
\text { indicators by } \\
\text { years }\end{array}$ & $\begin{array}{l}\text { Managerial } \\
\text { problem }\end{array}$ \\
\hline 2013 & 11521 & - & - & \multirow{7}{*}{2,317} & - & \\
\hline 2014 & 11884 & $\begin{array}{l}2014 / \\
2013\end{array}$ & 3,2 & & !!! & $\begin{array}{l}\text { Insufficient } \\
\text { growth trend }\end{array}$ \\
\hline 2015 & 12383 & $\begin{array}{l}2015 / \\
2014 \\
\end{array}$ & 4,2 & & !!! & $\begin{array}{l}\text { Insufficient } \\
\text { growth trend }\end{array}$ \\
\hline 2016 & 12380 & $\begin{array}{l}2016 / \\
2015\end{array}$ & $-0,1$ & & 0 & - \\
\hline 2017 & 12700 & $\begin{array}{l}2017 / \\
2016 \\
\end{array}$ & 2,6 & & !!! & $\begin{array}{l}\text { Insufficient } \\
\text { growth trend }\end{array}$ \\
\hline 2018 & 12736 & $\begin{array}{l}2018 / \\
2017 \\
\end{array}$ & 0,3 & & 0 & - \\
\hline 2019 & 13200 & $2019 / 2018$ & 3,7 & & !!! & $\begin{array}{l}\text { Insufficient } \\
\text { growth trend }\end{array}$ \\
\hline
\end{tabular}

Thus, in 2019 compared to 2018 there is an insufficient growth trend of the indicator characterizing the number of small and medium-sized enterprises in the region.

\section{DISCUSSING THE RESULTS}

Further, within the framework of the considered example, the author will show how a public servant can use the resources of the DSS "DATA" to form alternative managerial decisions. DSS "DATA" database contains possible alternative managerial decisions previously formed by the experts, as well as relations reflecting the influence of environmental disturbances on one of the targets of the National Projects of the Russian Federation which is a component of the RSES "The number of people employed in small and medium-sized enterprises, including individual entrepreneurs, million people." This allows moving on to production rules that form alternative managerial decisions for the RSES component "Number of employees in the field of small and medium-sized enterprises, including individual entrepreneurs, million people" based on various combinations of the environmental disturbance influence. At the next stage of the managerial decision-making process, a public servant can rely on the DSS "DATA" in determining the time for making managerial decisions. This is defined as a criterion for choosing managerial decisions from possible alternatives (described in [17]). Component RSES "The number of employees in the field of small and medium-sized enterprises, including individual entrepreneurs, million people" is estimated annually in the framework of the National Project, therefore, the time to adjust managerial decisions in accordance with [17] will be $t_{y}=4$ months. Accordingly, further the DSS "DATA" evaluates the possibility of implementing managerial decisions in terms of this time factor (Table 4). Consequently, part of the recommended managerial decisions is non-operational (for example, 12 or 18 months.)

Thus, at the end of describing the example of making a managerial decision at the regional level with the involvement of the DSS "DATA" resources, it can be noted that the mechanism considered will allow the civil servant to increase the efficiency of managerial activity, including by selecting exactly those decisions that can be successfully implemented by regional authority agencies.

\section{CONCLUSIONS}

DSS "DATA" may be applicable for accumulating and transferring the knowledge and experience of key specialists and successful leaders of public administration to ordinary managers and civil servants to support the decision-making process in the field of analyzing the impact of the external environment on the RSES. It is assumed that as a part of the civil servant's automated workstation, the software package will implement the support of making regional managerial decisions based on the analysis of the environmental impact on the RSES. The conceptual content of the developed software package is a diverse analysis of the external environment influence on the RSES and the subsequent formation of alternative managerial decisions based on artificial intelligence technologies. 
Table 4 Estimated time for making managerial decisions for the RSES component "Number of employees in the field of small and medium-sized enterprises, million people."

\begin{tabular}{|c|c|c|c|}
\hline \multirow[t]{2}{*}{$\begin{array}{l}\text { Alternative managerial decisions assigned in accordance with } \\
\text { the production rules }\end{array}$} & \multirow{2}{*}{$\begin{array}{l}\text { Possibility of } \\
\text { implementing a } \\
\text { managerial } \\
\text { decision in } \\
\text { accordance with } \\
\text { the criterion } \\
t_{\mathrm{y}}=4 \text { months }\end{array}$} & \multicolumn{2}{|c|}{$\begin{array}{l}\text { The nature of } \\
\text { managerial decisions }\end{array}$} \\
\hline & & $\begin{array}{l}\text { Operationa } \\
\quad 1\end{array}$ & Tactical \\
\hline $\begin{array}{l}\text { Providing small and medium-sized enterprises which implement } \\
\text { priority investment projects for the region with benefits, } \\
\text { subsidies and other forms of support within the framework of } \\
\text { state programs and projects }\end{array}$ & Yes & + & - \\
\hline $\begin{array}{l}\text { Supporting individual, small and medium-sized enterprises with } \\
\text { unique manufacturing experience }\end{array}$ & Yes & + & - \\
\hline $\begin{array}{l}\text { Ensuring joint actions and searching for partnership areas } \\
\text { between state executive bodies, business representatives and } \\
\text { non-profit (including public) organizations }\end{array}$ & Yes & + & - \\
\hline $\begin{array}{l}\text { Creating favorable conditions for developing social partnership } \\
\text { in the region }\end{array}$ & No & - & + \\
\hline $\begin{array}{l}\text { Creating conditions for developing external economic relations } \\
\text { with other regions of the Russian Federation (developing } \\
\text { relations with consumers, suppliers, distribution channels, } \\
\text { scientific partnerships, etc.) }\end{array}$ & No & - & + \\
\hline $\begin{array}{l}\text { Creating conditions for developing export-import relations, } \\
\text { including border areas }\end{array}$ & No & - & + \\
\hline
\end{tabular}

\section{REFERENCES}

[1] Vikhansky O.S., Mirakyan A.G. The new millennium: managerial anomalies and contemporary leadership concepts. Russian Management Journal. 2018. Vol. 16. No. 1. P. 131-154.

[2] Kuznetsova O.V. Trade-offs of spatial development priorities choice. Issues of economics (Voprosy economiki). 2019.No 1. S. 146-157.

[3] Kuznetsova O. V. Differences in Russian regions attractiveness for foreign and domestic investors. Issues of economics (Voprosy economiki). 2016. No. 4. P. 86102.

[4] Organizational issues of expert review and evaluation of macroregional development projects in Russia. Leksin V.N., Porfiryev B.N. Studies on Russian Economic Development. 2016. V. 27. № 6. P. 621-628.

[5] Evaluation of the effectiveness of government programs of socioeconomic development of regions of Russia. LeksinV.N., Porfiryev B.N. Studies on Russian Economic Development. 2016. V. 27. № 4. P. 418-428.
[6] Naumov A.I., Petrovskaya I.A. Dynamics of impact of national culture on business management in russia during 1996-2006. Eurasian Economic Review. 2010. P. 3.

[7] Naumov A.I., Petrovskaya I.A. Tendencies in changing the national culture of Russia from the perspective of its influence on business management in 1996-2006. EurasianEconomicReview. 2010. V. 3. № 6. P. 7.

[8] 8. Novikov D.A. Control systems classification. Management Issues (Problemy upravleniya). 2019.No 4.P. 27-42.

[9] Novikov D., Belov M. Methodological foundations of the digital economy. StudiesinSystems, DecisionandControl. 2019. V. 181. P. 3-14.

[10] System of measures to recovery of economic growth in Russia. Ivanter V.V., Govtvan O.D., Gusev M.S., Ksenofontov M.Y., Kuvalin D.B., Moiseev A.K., Porfiryev B.N., Semikashev V.V., Uzyakov M.N., Shirov A.A. Studies on Russian Economic Development. 2018. V. 29. № 1. P. 1-5. 
[11] Recovery of economic growth in Russia. Ivanter V.V., Belkina T.D., Belousov D.R., Blokhin A.A., Borisov V.N., Budanov I.A., Frolov I.E., Govtvan O.D., Gusev M.S., Komkov N.I., Korovkin A.G., Ksenofontov M.Y., Kuvalin D.B., Mikheeva N.N., Moiseev A.K., Panfilov V.S., Pappe Y.S., Polzikov D.A., Porfiriev B.N., Revich B.A. etal.Studies on Russian Economic Development. 2016. V. 27. № 5. P. 485-494.

[12] Shvecov A.N. Growth points or black holes: how efficient are state stimulation tools for territorial development? Regional Research of Russia. 2017. V. 7. № 2. P. 108-119.

[13] Logua, R.A., Khasanshin, I.A. Detailing the decision-making process for managing problem situations at the regional level / R.A. Logua, I.A. Khasanshin // Fundamentals of Economics, Management and Law, 2012. - P. 43-49.

[14] Averchenkova E.E., Averchenkov A.V., Gorlenko O.A., Miroshnikov V.V.. Machine-building Enterprise Fuzzy Model as the Interrelated Factor Complex System/International Conference on Information Technologies in Business and Industry 2016. IOP Conf. Series: Journal of Physics: Conf. Series 803 (2017) 012009 doi:10.1088/1742-6596/803/1/012009.

((идентификатор статьи в SCOPUS: 2-s2.085016636779).

[15] Averchenkova E.E., Averchenkov A.V. Kulagina N.A. Designing of the Information Advising System to Assess the Potential of Creation and Development of Cluster Agglomeration in the Industrial Complex of the Region / International Conference on Information Technologies in Business and Industry 2016. IOP Conf. Series: Journal of Physics: Conf. Series 803 (2017) 012011 doi:10.1088/1742-6596/803/1/012011((article id in SCOPUS: 2-s2.0-85018367471)

[16] Averchenkova E.E. The model of the external environment of the regional socio-economic system // Bulletin of computer and information technologies. 2020. No. 3. P. 19 - 28.

[17] Averchenkova E.E. Formalizing the representation of the regional socio-economic system as an object of management // Information systems and technologies. No. 2 (118) March-April 2020.P. 29-37.

[18] Averchenkova E.E. Management decisions as a negative feedback tool in the management system of the regional socio-economic system // Management Systems and Information Technologies, No. 1 (79), 2020. - P. 2831 